Research Paper:

\title{
Validity and Reliability of the Short Form Health Survey Questionnaire (SF-36) for Use in Iranian Patients With Traumatic Brain Injury (TBI)
}

\author{
Sajjad Rezaei ${ }^{1}$, Zahra Khaksari $^{* *}$ \\ 1. Department of Psychology, Faculty of Literature and Humanities, University of Guilan, Rasht, Iran \\ 2. Department of Psychology, Educational Sciences and Psychology, Payame Noor University, Tehran, Iran
}

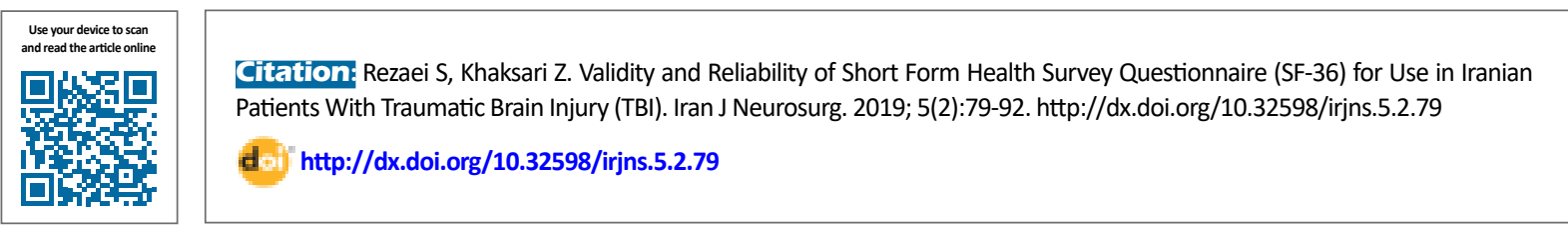

(a) 0

Article info:

Received: 02 Jan 2019

Accepted: 13 Mar 2019

Available Online: 01 April 2019

Keywords:

Brain injuries, Traumatic, Quality of Life, Surveys and questionnaires, Measurement, Reliability, Validity

\begin{abstract}
A B S T RACT
Background and Aim: The assessment of Quality of Life (QoL) as a measurement of Traumatic Brain Injury (TBI) outcome can play a key role in identifying the adverse effects of TBI. There is no study on the evaluation of psychometric properties of the Persian version of Short Form Health Survey Questionnaire (SF-36) in the TBI patient population. Therefore, the present study aimed to validate and test the reliability of the Persian version of the SF-36 in patients with TBI.
\end{abstract}

Methods and Materials/Patients: In the present cross-sectional study, 185 patients with TBI were selected by non-probability and consecutive sampling. First, the construct validity of the Persian version of the SF-36 questionnaire was evaluated using the Confirmatory Factor Analysis (CFA) in AMOS-22, and then the internal consistency reliability and item-total score correlation of each subscale were assessed by SPSS V. 22.

Results: Results of CFA indicated that the dimensionality of SF-29 questionnaire with eight-factor structure among the Iranian TBI patients had construct validity $(\mathrm{GFI}=0.825, \mathrm{CFI}=0.963, \mathrm{NFI}=0.919$, $\mathrm{TLI}=0.957$, RMSEA $=0.06$ ) by eliminating 6 items and freeing some of the covariance errors between items, but the two-factor dimensionality (physical and psychological components of $\mathrm{QoL}$ ) of this questionnaire was not approved. Internal consistency of the eight-factor form of SF29 subscales was acceptable to excellent $(=\alpha 0.70$ to 0.99$)$. Correlation analysis of item-total score for determining the construct validity of SF-29 indicated that except for 2 items, all items of the questionnaire had a positive and strong correlation with their subscales ( $r=0.40$ to $0.99, P<0.0001$ ).

Conclusion: Persian version of SF-29 with an eight-factor construct had good validity and reliability and could be used to measure health-related QoL in Iranian patients with TBI.

\section{* Corresponding Author:}




\section{Highlights}

- There is no study on the evaluation of psychometric properties of the Persian version of SF-36.

- The deleting 6 items due to obtaining the weak factor loading could improve values of fit indices in SF-29.

- The dimensionality of SF-29 questionnaire with eight-factor structure among the Iranian TBI patients had construct validity.

- The two-factor dimensionality (physical and psychological components of SF-36 \& SF-29) was not approved.

- Internal consistency of the eight-factor form of SF-29 subscales was acceptable to excellent.

\section{Plain Language Summary}

The assessment of Quality of Life (QoL) as a measurement of Traumatic Brain Injury (TBI) outcome can play a key role in identifying the adverse effects of TBI and the impact of different treatments on the progress of patient's recovery. Therefore, the present study aimed to validate and test the reliability of the Persian version of the Short Form Health Survey Questionnaire (SF-36) in patients with TBI. In the present cross-sectional study, 185 patients with TBI were selected by non-probability and consecutive sampling. First, the construct validity of the Persian version of the SF-36 questionnaire was evaluated, then the internal consistency reliability and item-total correlation of each subscale were assessed. Results indicated that the dimensionality of SF-29 questionnaire with eight-factor structure among the Iranian TBI patients had construct validity, but the two-factor dimensionality (physical and psychological components of QoL) of this questionnaire was not approved. Internal consistency of the eight-factor form of SF-29 subscales was acceptable to excellent ( $\alpha=0.70$ to 0.99 ). Correlation analysis of item-total score for determining the construct validity of SF-29 indicated that except for 2 items, all items of the questionnaire had a positive and strong correlation with their subscales. The Persian version of SF-29 with an eight-factor construct had good validity and reliability and could be used to measure health-related QoL in Iranian patients with TBI.

\section{Introduction}

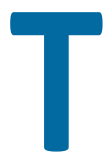

raumatic Brain Injury (TBI) is a major cause of mortality and disability, especially among young people and those under the age of $45[1,2]$. Approximately 69 million people worldwide suffer from traumatic brain injury every year. From 100,000 people, 1299 in the USA and 1012 in Europe suffer from TBI [3]. With regards to the statistics, Iran is one of the leading countries in terms of the number of the annual accidents and injuries, which unfortunately occur mostly in the head and neck areas with a predilection for brain injuries. Nationwide, traumatic brain injury is the second most common cause of mortality in injured patients [4]. TBI may occur in accidents due to motor vehicles, fall from a height, attacks, and so on. Manifestations of this injury can range from severe fatigue to loss of consciousness and depend on the severity of TBI [5].

A great number of patients with moderate and severe TBI suffer from long-term physical, cognitive, emotional, social and occupational consequences that adversely affect their performance and quality of life [6]. The assessment of the quality of life of people with TBI plays a significant role in the creation of suitable strategies for each person that allows us to guide effective and rehabilitative therapies [7].

The Short Form Health Survey Questionnaire (SF-36) is an accepted reporting tool to assess the health-related quality of life in people with TBI [8-10]. In a meta-analysis study on published research on TBI from 1991 to 2013, Polinder et al (2015) stated that SF-36 was the most comprehensive tool for assessing the quality of life of patients with TBI [11]. For years, the SF-36 has been a common questionnaire to assess the Health-Related Quality of Life (HRQoL) among different populations and has been translated into Persian, and its psychometric properties have been evaluated in Iran. Also, it has been utilized in studies on TBI in Iran; however, there is no study on the evaluation of psychometric properties of the Persian version of SF-36 in the TBI patient population [12-15]. 
The literature review indicates that English versions of SF-36 are previously examined by Findler et al. and MacKenzie et al. in TBI patients and their psychometric properties are confirmed, while based on studies in Iran, psychometric properties of the Persian version of SF-36 has been examined only in groups such as healthy populations, thalassemia major, elderly and MS patients $[8,13,16-21]$. There is a research gap to investigate the psychometric properties of the Persian version of SF-36 in Iranian TBI patients.

The use of quality of life measures can provide information on the general health status of TBI patients for experts, otherwise, they may not be detectable. In this regard, SF-36 can have growing importance to evaluate disease progression, treatment and care management of patients with TBI. Therefore, the present study aimed to validate the SF-36 for use in Iranian patients with TBI.

\section{Methods and Materials/Patients}

This study was conducted in Emergency and Neurosurgery Departments of Poursina Hospital of Rasht (North of Iran). In a cross-sectional study, a total of 185 patients with TBI were selected before discharge from the hospital by a census and consecutive sampling method to examine the internal consistency of SF-36 and construct validity and its two-factor construct.

\section{Inclusion and exclusion criteria}

Inclusion criteria for all patients, who were diagnosed with mild to moderate TBI based on specialist's diagnosis, were as follows: Age of 16 and older; and Glasgow Coma Scale (GCS) of 8 and higher. Exclusion criteria included clinical or radiologic findings indicating spinal cord injury; any neurological disease before the TBI, or non-traumatic brain injury (such as brain tumors, stroke, arterial aneurysm and other cerebrovascular events); vegetative state or severe consciousness deficit and being unable to respond to tests; presence of movement or balance disorders, arthritis, fracture of knee and joints before TBI; and refusal to give consent to enter the study for any reason.

\section{Patients' evaluation}

Referral to the emergency and neurosurgery departments of the hospital was performed (Everyday except for the official holidays) by two trained senior nursing experts for daily sampling (9.00 AM to $1.00 \mathrm{PM}$ ). Patients eligible for inclusion in this study were identified by neurosurgical diagnosis and review of their hospital records within 72 hours after their arrival at the hospital. The initial evaluation was then performed on them by SF-36. At the beginning of the evaluation of patients with $\mathrm{TBI}$, the reasons for conducting the research and the method were explained for participants or their attendants and they were assured that their information would be kept confidential.

It was also reminded that their refusal to participate in the study would not have any impact on their treatment process. All eligible patients were evaluated before discharge. Demographic data were collected and quality of life assessment was performed after entering patients with obtained informed consent from either the patients or the families. In the next step, demographic data and some clinical information (such as the exact duration of hospital stay), results of neurosurgical examinations and neuroimaging findings (CT scan) were extracted from their hospital records until the evaluation day.

\section{Research tool}

Short Form Health Survey Questionnaire (SF-36): The questionnaire was designed by Ware et al. to assess the quality of life. It has 36 questions with two general performance measures (see appendix), namely the Physical Component Summary (PCS), which examines the physical dimension of health, and the Mental Component Summary (MCS) which also measures the psychosocial aspect of health $[15,22]$. It should be noted that the second item of this questionnaire is not calculated in any of the subscales. Scale scores range from 0 to 100 , with 100 indicating the most favorable health status.

The aggregated PCS and MCS scores are standardized to have a mean of 50 and a standard deviation of 10 [22]. The reliability and validity of this questionnaire were evaluated by Asghari Moghaddam and Faghehi in two studies on Shahed University students [14]. In the first study, 404 male and female students responded to the questionnaire. In order to investigate test-retest coefficients of the SF-36 subscales, the questionnaire was again implemented on 120 participants (60 girls and 60 boys) from the same participants after a week.

The results indicated that there were desirable internal consistency and reliability of all subscales of the questionnaire (test-retest coefficients of subscales ranged from 0.43 to 0.79 and Cronbach's alpha coefficients of subscales ranged from 0.70-0.85). In the second study, the validity of the Health Questionnaire was assessed by implementing in two groups, healthy ones 
$(n=48)$ and patients $(n=81)$. Scores of both healthy and patient groups were compared on all subscales of the questionnaire. The results indicated statistically significant differences in all subscales of the questionnaire in both groups. The findings of the two studies indicated an acceptable validity and reliability of the SF-36 questionnaire in an Iranian adult sample [14].

\section{Data analysis}

The Confirmatory Factor Analysis (CFA) technique was used with a maximum likelihood to determine the presence of 8 factors and then two general domains in order to determine the construct validity of the above mentioned cases. Fit indices of eight-factor and twofactor models were evaluated in 185 samples and their results were compared using AMOS-22. The Cronbach's alpha coefficients were used to obtain the internal con- sistency reliability of SF-36 domains and components. The item-total correlation coefficients were calculated for each subscale of SF-36 to evaluate the construct validity. These statistical analyses were performed by a significance level of less than $\mathrm{P}<0.05$ using the SPSS software V. 22

\section{Results}

Table 1 presents the findings of the demographic and contextual variables of patients with TBI $(n=185)$. The mean age of patients was $37.50 \pm 17.42$ years and ranged from 15 to 85 years. To obtain a more appropriate model in the Iranian patients with TBI, both eight-domain and two-component/factor models plus modification indices were used based on the AMOS output (Table 2). The output of CFA indicated that freeing a number of covariance errors between items and deleting 6 items due to

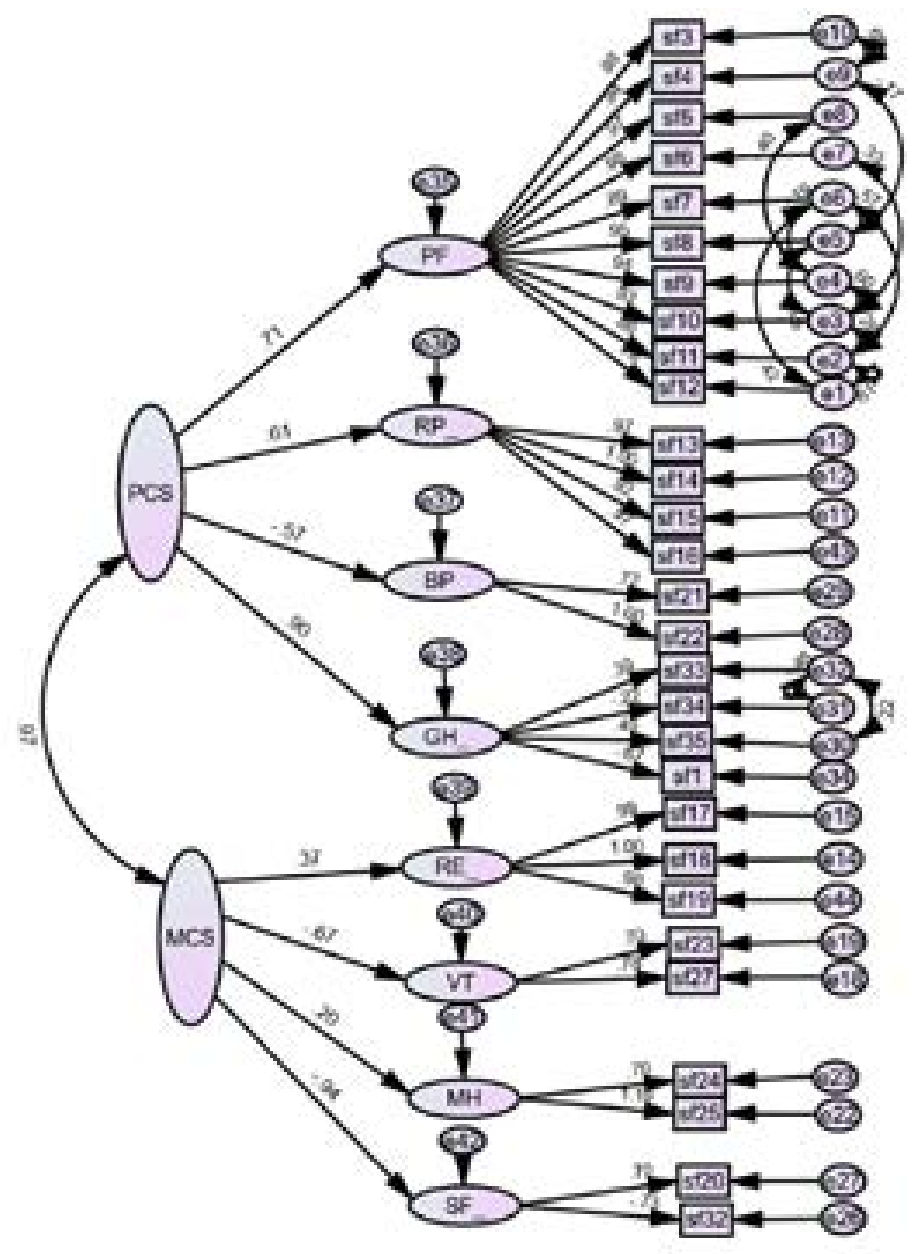

Figure 1. Factor loadings and measurement error of SF-29 questionnaire items in the eight-factor model

PF: Physical Function; RP: Role Physical; BP: Bodily Pain; GH: General Health; VT: Vitality; SF: Social Function; RE: Role Emotional; MH: Mental Health 
Table 1. Demographic and clinical characteristics of patients with traumatic brain injury $(n=185)$

\begin{tabular}{|c|c|c|}
\hline \multicolumn{2}{|c|}{ Characteristics } & \multirow{2}{*}{$\begin{array}{c}\text { No. (\%) } \\
171(92.4)\end{array}$} \\
\hline & Male & \\
\hline Ucrier & Female & $14(7.6)$ \\
\hline \multirow{3}{*}{ Marital status } & Single & $66(35.7)$ \\
\hline & Married & $118(63.8)$ \\
\hline & Not reported & $1(0.5)$ \\
\hline \multirow{3}{*}{ Residence } & Village & 101(54.6) \\
\hline & City & $81(43.8)$ \\
\hline & Not reported & $3(1.6)$ \\
\hline \multirow{7}{*}{ Occupational status } & Professional & $1(0.5)$ \\
\hline & Office & $20(10.8)$ \\
\hline & Technical & $33(17.8)$ \\
\hline & Skilled worker & $67(36.2)$ \\
\hline & Simple worker & $40(21.6)$ \\
\hline & Unemployed & 19(10.3) \\
\hline & Not reported & $5(2.7)$ \\
\hline \multirow{9}{*}{ TBI cause } & Cars & $27(14.6)$ \\
\hline & Motorcycle & $91(49.2)$ \\
\hline & Pedestrian & $15(8.1)$ \\
\hline & Fall & $16(8.6)$ \\
\hline & Violence & $5(2.7)$ \\
\hline & Clash of objects & $11(5.9)$ \\
\hline & Drop back & 18(9.7) \\
\hline & Riding bike & $1(0.5)$ \\
\hline & Not reported & $1(0.5)$ \\
\hline \multirow{6}{*}{ Skull fracture } & No & $118(63.8)$ \\
\hline & Simple (linear) & $47(25.4)$ \\
\hline & Depressed & $16(8.6)$ \\
\hline & Basilar & $2(1.1)$ \\
\hline & Mixed & $1(0.5)$ \\
\hline & Indeterminate & $1(0.5)$ \\
\hline \multirow{5}{*}{ Hemispheric brain injury } & No & $20(10.8)$ \\
\hline & Left & 59(31.9) \\
\hline & Right & $78(42.2)$ \\
\hline & Bilateral & $25(13.5)$ \\
\hline & Indeterminate & $3(1.6)$ \\
\hline
\end{tabular}


Table 2. Eight- and two-factor model fit indices of Short Form Health Survey Questionnaire

\begin{tabular}{|c|c|c|c|c|}
\hline Fit Indices & $\begin{array}{l}\text { Observed Values } \\
\text { in the Original } \\
\text { 8-factor Model } \\
\text { With } 36 \text { Items }\end{array}$ & $\begin{array}{l}\text { Observed Values } \\
\text { in the Improved } \\
\text { 8-factor Model } \\
\text { With } 29 \text { Items }\end{array}$ & $\begin{array}{l}\text { Observed Values } \\
\text { in the Original } \\
\text { 2-factor Model } \\
\text { With } 36 \text { Items }\end{array}$ & $\begin{array}{l}\text { Observed Values } \\
\text { in the Improved } \\
\text { 2-factor Model } \\
\text { With } 29 \text { Items }\end{array}$ \\
\hline$\left(\chi^{2}\right)$ & 1909.490 & 663.547 & 3689.577 & 1201.562 \\
\hline (df) & 551 & 382 & 560 & 320 \\
\hline (P-Value) & 0.0001 & 0.0001 & 0.0001 & 0.0001 \\
\hline$\left(\chi^{2} / d f\right)$ & 3.465 & 1.760 & 6.589 & 2.818 \\
\hline Goodness of Fit Index (GFI) & 0.634 & 0.825 & 0.448 & 0.777 \\
\hline Adjusted Goodness of Fit Index (AGFI) & 0.582 & 0.779 & 0.379 & 0.716 \\
\hline Normed Fit Index (NFI) & 0.775 & 0.919 & 0.564 & 0.876 \\
\hline Tucker-Lewis Index (TLI) & 0.814 & 0.957 & 0.578 & 0.900 \\
\hline Comparative Fit Index (CFI) & 0.828 & 0.963 & 0.603 & 0.916 \\
\hline Akaike Information Criterion (AIC) & 2067.490 & 784.974 & 3829.577 & 1073.841 \\
\hline $\begin{array}{l}\text { Root Mean Square Error of Approximation } \\
\text { (RMSEA) }\end{array}$ & 0.11 & 0.06 & 0.17 & 0.09 \\
\hline
\end{tabular}

obtaining the weak factor loading $(36,31,30,29,28$ and 26) could improve the values of fit indices (see Figure 1).

Due to modification indices $(\mathrm{GFI}=0.825, \mathrm{CFI}=0.963$, $\mathrm{NFI}=0.919, \mathrm{TLI}=0.957$, RMSEA $=0.06$ ) and the lack of inclusion of item 2 in subscale calculations, the eightfactor model with 29 items and freeing 14 covariance errors between items " 3 and 4", "11 and 12", "10 and 11 ", "9 and 10", "7 and 8", "8 and 9", "4 and 8", "6 and 10 ", "7 and 11", "6 and 9", "7 and 8", " 8 and 10", "33 and 35 " and "33 and 34" were preferred to the two-factor model with 29 items and freeing 27 covariance errors between items " 3 and 9", "3 and 4", "4 and 8", "5 and 36", " 1 and 7", "7 and 12", "7 and 11", "9 and 10", "11 and 12", "1 and 12", "13 and 14", "14 and 16", "21 and 22", "6 and 36", " 1 and 35", "12 and 22", "9 and 16", "6 and 16", "4 and 10", "5 and 10", "6 and 9", "5 and 9", "7 and 9", "10 and 11", "24 and 25", "26 and 30" and "28 and $31^{\prime \prime}$.

The results indicated that dimensionality of eight-factor SF-29 questionnaire among the Iranian TBI patients compared to the two-factor model has more favorable fit indices and higher construct validity (Table 2 ). The el-

Table 3. Descriptive indices and internal consistency reliability coefficients for subscales of SF-29 questionnaire ( $n=185)$

\begin{tabular}{ccc}
\hline Subscales & Mean \pm SD & Cronbach's Alpha \\
\hline PF & $95.49 \pm 35.12$ & 0.98 \\
RP & $45.08 \pm 14.67$ & 0.98 \\
BP & $12.07 \pm 5.03$ & 0.83 \\
GH & $20.95 \pm 4.08$ & 0.86 \\
VT & $12.8 \pm 5.11$ & 0.70 \\
SF & $12.73 \pm 3.16$ & 0.90 \\
RE & $25.71 \pm 17.23$ & 0.99 \\
MH & $5.56 \pm 4.92$ & 0.91 \\
PCS & $31.84 \pm 5.67$ & 0.91 \\
MCS & $23.61 \pm 6.63$ & 0.87 \\
\hline
\end{tabular}

PF: Physical Function; RP: Role Physical; BP: Bodily Pain; GH: General Health; VT: Vitality; SF: Social Function; RE: Role Emotional; MH: Mental Health; PCS: Physical Component Summary, MCS: Mental Component Summary. 


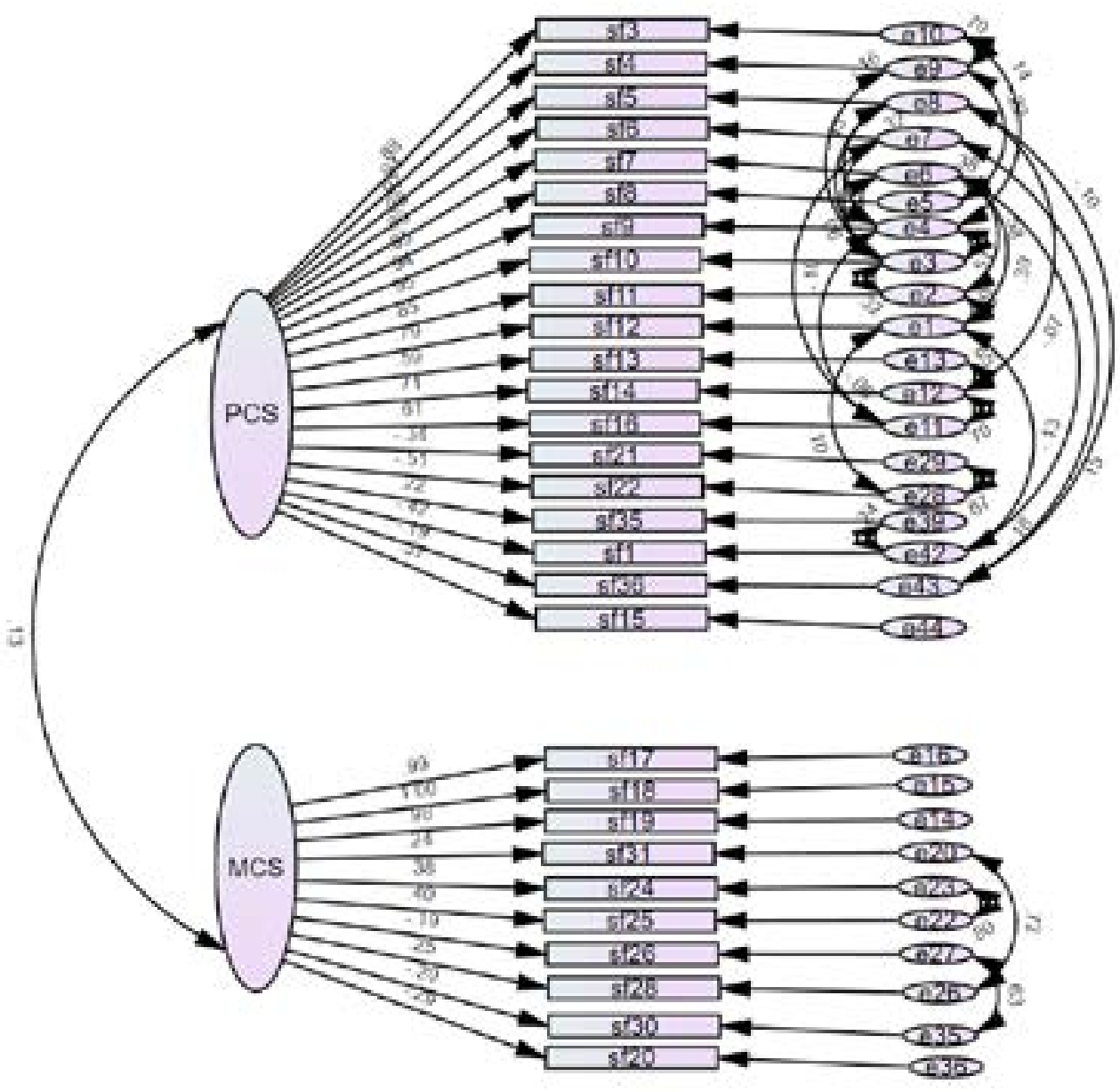

Figure 2. Factor loadings and measurement error of SF-29 questionnaire items in a two-factor model

PCS: Physical Component Summary, MCS: Mental Component Summary

lipses contain latent variables or factors, and the rectangles are SF-29 items. The two-way arrows indicate the correlation between factors, and the one-way arrows from ellipses to squares indicate the place of items on factor loading. The written values on these arrows indicate the correlation coefficient of items with each factor, and small arrows from circles to squares represent the residual variance (error) that cannot be explained by the factor. The error values are obtained by subtracting the explained variances from number 1 .

Table 3 presents descriptive indices and internal consistency reliability coefficients for the eight subscales of the SF-29 questionnaire. Based on Table 3, Cronbach's alpha coefficients which are used to obtain the internal consistency reliability of the questionnaire indicate the reliability of all subscales of SF-29 in the range of 0.70 to 0.99 which is equal to or greater than the recommended value for acceptance of internal consistency [23]. Table
4 presents the item-total score correlation coefficients of SF-29 subscales.

Table 4 presents that the results of all correlations between each item with its total subscale score are significant in all cases $(P<0.0001)$. In other words, each item has a significant correlation with the sub-scale; hence, each of eight subscales of the SF-29 questionnaire measures a separate dimension of quality of life. All correlation coefficients for each item and subscale, except for items 32 and 34, exceed the recommended minimum level of $>0.40$ [24] indicating the construct validity of SF-29. In this regard, the lowest correlation coefficient is 0.25 (GH34) and the highest correlation coefficient is 0.99 (RP14, RE17, RE18, RE19).

\section{Discussion}

The present study aimed to validate and test the reliability of SF-36 for using in Iranian patients with TBI. 
Table 4. Correlation of item-total score of subscale for eight-factor version of SF-29 ( $n=185)$

\begin{tabular}{|c|c|c|c|c|c|c|c|c|c|}
\hline Subscales & Items & 1 & 2 & 3 & 4 & 5 & 6 & 7 & 8 \\
\hline \multirow{10}{*}{ PF } & 3 & 0.89 & 0.52 & 0.45 & 0.02 & 0.09 & 0.27 & 0.01 & 0.01 \\
\hline & 4 & 0.93 & 0.59 & 0.46 & 0.02 & 0.13 & 0.24 & 0.05 & 0.06 \\
\hline & 5 & 0.95 & 0.56 & 0.45 & 0.03 & 0.15 & 0.29 & 0.05 & 0.11 \\
\hline & 6 & 0.96 & 0.57 & 0.44 & 0.005 & 0.10 & 0.29 & 0.03 & 0.08 \\
\hline & 7 & 0.92 & 0.52 & 0.43 & 0.03 & 0.16 & 0.25 & 0.06 & 0.12 \\
\hline & 8 & 0.95 & 0.54 & 0.43 & 0.05 & 0.09 & 0.27 & 0.03 & 0.09 \\
\hline & 9 & 0.94 & 0.53 & 0.40 & 0.04 & 0.05 & 0.30 & 0.01 & 0.07 \\
\hline & 10 & 0.95 & 0.58 & 0.41 & 0.03 & 0.08 & 0.32 & 0.03 & 0.08 \\
\hline & 11 & 0.91 & 0.53 & 0.40 & 0.03 & 0.16 & 0.27 & 0.06 & 0.13 \\
\hline & 12 & 0.85 & 0.49 & 0.43 & 0.06 & 0.18 & 0.29 & 0.02 & 0.06 \\
\hline \multirow{4}{*}{$\mathrm{RP}$} & 13 & 0.57 & 0.97 & 0.33 & 0.01 & 0.42 & 0.20 & 0.16 & 0.04 \\
\hline & 14 & 0.57 & 0.99 & 0.32 & 0.02 & 0.45 & 0.19 & 0.16 & 0.04 \\
\hline & 15 & 0.55 & 0.95 & 0.34 & 0.03 & 0.46 & 0.19 & 0.16 & 0.05 \\
\hline & 16 & 0.58 & 0.97 & 0.33 & 0.001 & 0.47 & 0.20 & 0.17 & 0.05 \\
\hline \multirow{2}{*}{$\mathrm{BP}$} & 21 & 0.34 & 0.27 & 0.92 & 0.01 & 0.11 & 0.15 & 0.01 & 0.008 \\
\hline & 22 & 0.51 & 0.35 & 0.93 & 0.04 & 0.12 & 0.20 & 0.06 & 0.06 \\
\hline \multirow{4}{*}{$\mathrm{GH}$} & 1 & 0.45 & 0.25 & 0.29 & 0.40 & 0.10 & 0.32 & 0.06 & 0.12 \\
\hline & 33 & 0.18 & 0.19 & 0.02 & 0.41 & 0.33 & 0.22 & 0.22 & 0.17 \\
\hline & 34 & 0.02 & 0.05 & 0.03 & 0.25 & 0.31 & 0.21 & 0.10 & 0.08 \\
\hline & 35 & 0.22 & 0.15 & 0.28 & 0.51 & 0.25 & 0.11 & 0.20 & 0.05 \\
\hline \multirow{2}{*}{ VT } & 23 & 0.32 & 0.22 & 0.18 & 0.11 & 0.18 & 0.69 & 0.08 & 0.01 \\
\hline & 27 & 0.38 & 0.25 & 0.23 & 0.04 & 0.17 & 0.77 & 0.05 & 0.001 \\
\hline \multirow{2}{*}{ SF } & 20 & 0.43 & 0.35 & 0.30 & 0.03 & 0.29 & 0.28 & 0.13 & 0.68 \\
\hline & 32 & 0.46 & 0.40 & 0.35 & 0.05 & 0.17 & 0.29 & 0.15 & 0.28 \\
\hline \multirow{3}{*}{ RE } & 17 & 0.14 & 0.46 & 0.12 & 0.09 & 0.99 & 0.05 & 0.39 & 0.18 \\
\hline & 18 & 0.13 & 0.46 & 0.14 & 0.10 & 0.99 & 0.05 & 0.41 & 0.17 \\
\hline & 19 & 0.13 & 0.46 & 0.12 & 0.10 & 0.99 & 0.05 & 0.41 & 0.18 \\
\hline \multirow{2}{*}{$\mathrm{MH}$} & 24 & 0.01 & 0.13 & 0.08 & 0.13 & 0.38 & 0.09 & 0.96 & 0.01 \\
\hline & 25 & 0.06 & 0.19 & 0.009 & 0.16 & 0.40 & 0.04 & 0.95 & 0.04 \\
\hline
\end{tabular}

Note: PF: Physical Function; RP: Role Physical; BP: Bodily Pain; GH: General Health; VT: Vitality; SF: Social Function; RE: Role Emotional; MH: Mental Health

Results of the CFA for investigating a 8-factor construct of the SF-36 questionnaire and measuring values of fit indices of model and comparing its results with a twofactor construct of questionnaire indicated that values of fit indices could be improved by eliminating 6 items $(36,31,30,29,28$, and 26) and freeing some of the covariance errors between items (Figure 2). The results indicated that the dimensionality of the questionnaire with 29 items and an eight-factor construct had good construct validity, but the dimensionality of the two-factor construct of this tool was not approved in this group.
However, two GFI and AGFI fit indices were lower than the acceptable extent (i.e. 0.90). The reason for the weakness of these two indices is the high complexity of the model (eight factors, 29 items, and thus a high degree of freedom) and also the scant sample size [25]. Therefore, for future researches, it is recommended to use a larger TBI sample to confirm the underlying factors of SF-36.

Consistent with the present study, findings of research by Guilfoyle et al. also confirmed eight dimensions of SF-36 as criteria for evaluation of HRQoL in patients 
with TBI, but they indicated that PCS and MCS dimensions were not valid in this regard [9].

Yang et al. also confirmed the eight-factor construct of SF-36 and recommended its use for TBI patients and for varied racial specimens by providing model fit indices for 654 elderly patients with TBI with a mean age of 72 years (white people: $87 \%$; black people: $13 \%$ ) [10].

Similar results have been reported for the dimensionality of SF-36 in validation studies under other neurological conditions. Hobart et al. studied a group of patients, who had stroke 11 months ago, and supported an eightfactor construct of this SF-36, but they also found that factor loadings of a two-factor construct were not consistent with to views of first designers of SF-36 [26]. In the investigation of SF-36 scaling on patients with Parkinson's disease, Hagell et al. due to item scaling of SF36 supported 8 scales and their reliability, but they did not consider two summarized indices of SF-36 as valid factors of physical and mental health [27].

In the present study, the findings of Cronbach's alpha coefficients for determining internal consistency reliability of all subscales of SF-29 were equal to or greater than 0.70 . The highest obtained alpha equal to 0.99 belonged to the RE subscale. It can be thus concluded that SF-29 subscales have great homogeneity and consistency and evaluate a concept. Previous studies examined psychometric properties of SF-36 in patients with $\mathrm{TBI}$ and achieved similar results. For instance, Findler et al. evaluated the reliability of the American version of the SF-36 questionnaire in TBI patients $(n=326)$ and reported Cronbach's alpha coefficient of subscales equal to 0.83 to 0.91 for patients with mild TBI and 0.79 to 0.92 for patients with moderate to severe TBI [8].

Yang et al. evaluated 551 patients with TBI and found that internal consistency reliability of SF-36 ranged from 0.81 to 0.95 for patients for all subscales [10]. Other studies in similar populations reported Cronbach's alpha coefficients ranging from 0.76 to 0.95 [9, 16, 28]. In Iranian research samples, there is no study containing samples homogeneous with the present study on psychometric properties of SF-36, but Jafari et al. evaluated psychometric properties of this questionnaire in 200 patients with thalassemia major and found that the internal consistency reliability of all subscales except for Role Emotional ( $\alpha=0.65$ ) that was 0.70 or higher [18].

Results of the present study on item-subscale correlation indicated that all items of SF-29 except for 32 and 34 items had a strong and positive correlation ranging from 0.40 and 0.99 with their subscales, and the value was above the minimum desired level of $\leq 0.40$ [29]; and 19 items of the questionnaire with values of higher than 0.91 were related to their respective subscales. In other words, SF-29 had good internal consistency and construct validity. Guilfoyle et al. reported the correlation of all items except for 6 items with subscales of SF-36 in the range of 0.53 to 0.86 [9].

In the present study, respondents to SF-36 had different intensities and symptoms of TBI. This factor affects the distribution of responses. Six items of the original SF-36 were excluded in the present study. It clarifies that tools for the general population cannot be simply implemented in a clinical sample. In the future, it is necessary to evaluate the quality of life of patients and the testretest reliability of SF-36 after removing confounding demographic factors. Since adverse outcomes of TBI on quality of life cannot be obtained only by SF-36 scores, using this test alone is not recommended. Therefore, using the improved 8-factor form (SF-29) is suggested to measure health-related quality of life in Iranian patients with TBI.

\section{Conclusion}

In general, the results indicated that SF-29 had satisfactory psychometric properties among patients with TBI and could be used as a tool for therapists and rehabilitation specialists in research and therapeutic interventions to measure and monitor the quality of life of Iranian patients with TBI.

\section{Ethical Considerations}

Compliance with ethical guidelines

The study was approved by the Deputy for Research \& Technology, Guilan University of Medical Sciences, (P-3-132-4618). In this study, no intervention in medical treatment was performed. All questioners were anonymous. Participants were assured about the confidentiality of their information, the voluntariness of participation in, and withdrawal from the study. The present study was approved by the Ethics Committee of PourSina Hospital of Rasht (No: 6930459717). Informed consent was obtained from all of the participants.

Funding

This article is based on a research project developed by Sajjad Rezaei in Guilan Road Trauma Research Center 
(registered project number: P-3-132-4618) funded by Guilan University of Medical Sciences.

\section{Authors contributions}

All authors contributed in designing, running, and writing all parts of the research.

\section{Conflict of interest}

The authors declared no conflict of interest.

\section{Acknowledgements}

The authors also appreciate the support by physicians and nurses in Guilan Road Trauma Research Center in the neurosurgical assessment of patients with TBI.

\section{References}

[1] Werner C, Engelhard K. Pathophysiology of traumatic brain injury. British Journal of Anaesthesia. 2007; 99(1):4-9. [DOI:10.1093/bja/aem131] [PMID]

[2] Jenkins DR, Craner MJ, Esiri MM, DeLuca GC. Contribution of fibrinogen to inflammation and neuronal density in human traumatic brain injury. Journal of Neurotrauma. 2018, 35(19):2259-71. [DOI:10.1089/neu.2017.5291] [PMID]

[3] Dewan MC, Rattani A, Gupta S, Baticulon RE, Hung YC, Punchak $\mathrm{M}$, et al. Estimating the global incidence of traumatic brain injury. Journal of Neurosurgery. 2019; 130(4):1080-97. [DOI:10.3171/2017.10.JNS17352] [PMID]

[4] Ebrahimi Fakhar HR, Moshiri E, Zand S. [An investigation on quality of emergency care of head injury patients in emergency ward, Vali-e-Asr hospital, Arak 2005 (Persian)]. Journal of Arak University Medical Sciences. 2008; 10(4):1-12.

[5] Styrke J, Stålnacke BM, Sojka P, Björnstig U. Traumatic brain injuries in a well-defined population: epidemiological aspects and severity. Journal of Neurotrauma. 2007; 24(9):1425-36. [DOI:10.1089/neu.2007.0266] [PMID]

[6] Groswasser Z, Peled I, Ross S, Truelle JL, Von Steinbüchel N. Validation of the QOLIBRI - Quality of Life after Brain Injury questionnaire in patients after TBI in Israel. Brain Injury. 2018; 32(7):879-88. [DOI:10.1080/02699052.2018.1466196] [PMID]

[7] Fernández M, Verdugo MÁ, Gómez LE, Aguayo V, Arias B. Core indicators to assess quality of life in population with brain injury. Social Indicators Research. 2018; 137(2):813-28. [DOI:10.1007/s11205-017-1612-6]

[8] Findler M, Cantor J, Haddad L, Gordon W, Ashman T. The reliability and validity of the SF-36 health survey questionnaire for use with individuals with traumatic brain injury. Brain Injury. 2001; 15(8):715-23. [DOI:10.1080/02699050118193] [PMID]

[9] Guilfoyle MR, Seeley HM, Corteen E, Harkin C, Richards $\mathrm{H}$, Menon DK, et al. Assessing quality of life after traumatic brain injury: Examination of the short form 36 health survey Journal of Neurotrauma. 2010; 27(12):2173-81. [DOI:10.1089/ neu.2010.1353] [PMID]

[10] Yang C, Selassie AW, Carter RE, Tilley BC. Measuring QoL with SF-36 in older Americans with TBI. Applied Research in Quality of Life. 2012; 7(1):63-81. [DOI:10.1007/s11482-0119148-4] [PMID] [PMCID]

[11] Polinder S, Haagsma JA, van Klaveren D, Steyerberg EW, Van Beeck EF. Health-related quality of life after TBI: A systematic review of study design, instruments, measurement properties, and outcome. Population Health Metrics. 2015; 13:4. [DOI:10.1186/s12963-015-0037-1] [PMID] [PMCID]

[12] Cordier R, Brown T, Clemson L, Byles J. Evaluating the longitudinal item and category stability of the SF-36 full and summary scales using rasch analysis. BioMed Research International. 2018; 2018:1013453. [DOI:10.1155/2018/1013453] [PMID] [PMCID]

[13] Montazeri A, Goshtasebi A, Vahdanian M, Gandek B. The short form health survey (SF-36): Translation and validation study of the Iranian version. Quality of Life Research. 2005; 14(3):875-82. [DOI:10.1007/s11136-004-1014-5] [PMID]

[14] Asghari Moghaddam MA, Faghehi S. [Validation of the SF-36 health survey questionnaire in two Iranian samples (Persian)]. Clinical Psychology \& Personality. 2003; 1(1):1-10.

[15] Dehnadi-Moghadam A, Rezaei S, Khodadadi N, Rahmatpour P. Psychometric properties of the Functional Independence Measure (FIM) in Iranian patients with traumatic brain injury. Trauma Monthly. 2017; 22(1):e25534. [DOI:10.5812/ traumamon.25534]

[16] MacKenzie EJ, McCarthy ML, Ditunno JF, Forrester-Staz C, Gruen GS, Marion DW, et al. Using the SF-36 for characterizing outcome after multiple trauma involving head injury. Journal of Trauma and Acute Care Surgery. 2002; 52(3):52734. [DOI:10.1097/00005373-200203000-00018] [PMID]

[17] Habibi M, Khodaei E, Moghadamzadeh A, Shamsedini S, Barekatain M. [Psychometric properties and hierarchical factor structure of short form health survey scale (SF-36) in a non-clinical sample (Persian)]. Journal of Research in Behavioral Sciences. 2012; 10(6):472-90.

[18] Jafari H, Lahsaeizadeh S, Jafari P, Karimi M. Quality of life in thalassemia major: Reliability and validity of the Persian version of the SF-36 questionnaire. Journal of Postgraduate Medicine. 2008; 54(4):273-5. [DOI:10.4103/0022-3859.41432] [PMID]

[19] Eshaghi SR, Ramezani MA, Shahsanaee A, Pooya A. Validity and reliability of the short form- 36 items questionnaire as a measure of quality of life in elderly Iranian population American Journal of Applied Sciences. 2006; 3(3):1763-6. [DOI:10.3844/ajassp.2006.1763.1766]

[20] Asadollahi A, Ismaeli A, Fani Saberi L. [Validity and reliability of quality of life test among Ahvaz older adults in 2016 (Persian)]. 2016; 8(32):7-15.

[21] Salehpoor Gh, Kafi SM, Salehi I, Rezaei S. Psychometric characteristics of the health survey questionnaire (SF-36) for evaluation of multiple sclerosis: Psychometric evaluation in Iranian patients. Jundishapur Scientific Medical Journal. 2015; 14(4):367-84. 
[22] Ware JE Jr, Kosinski M, Keller SD. SF-36 physical and mental health summary scales: A user's manual. Boston, MA New England Medical Center; 1994.

[23] Ware JE Jr, Snow KK, Kosinski M, Gandek B. SF-36 health survey: Manual and interpretation guide. Boston, MA: New England Medical Center; 1993.

[24] Westen D, Rosenthal R. Quantifying construct validity: Two simple measures. Journal of Personality and Social Psychology. 2003; 84(3):608-18. [DOI:10.1037//00223514.84.3.608] [PMID]

[25] MacCallum RC, Hong S. Power analysis in covariance structure modeling using GFI and AGFI. Multivariate Behavioral Research. 1997; 32(2):193-210. [DOI:10.1207/ s15327906mbr3202_5] [PMID]

[26] Hobart JC, Williams LS, Moran K, Thompson AJ. Quality of life measurement after stroke: Uses and abuses of the SF-36. Stroke. 2002; 33(5):1348-56. [DOI:10.1161/01. STR.0000015030.59594.B3] [PMID]

[27] Hagell P, Törnqvist AL, Hobart J. Testing the SF-36 in Parkinson's disease. Journal of Neurology. 2008; 255(2):246-54. [DOI:10.1007/s00415-008-0708-y] [PMID]

[28] Von Steinbuechel N, Covic A, Polinder S, Kohlmann T, Cepulyte U, Poinstingl $\mathrm{H}$, et al. Assessment of health-related quality of life after TBI: Comparison of a disease-specific (QOLIBRI) with a generic (SF-36) instrument. Behavioural Neurology. 2016; 2016:7928014. [DOI:10.1155/2016/7928014] [PMID] [PMCID]

[29] Nunnally JC, Bernstein IH. Psychometric theory, $3^{\text {rd }}$ ed. New York: McGraw-Hill; 1994. 


\section{Appendix}

Appendix: Persian version of the SF-36 questionnaire adapted for TBI patients

سوالات زير به منظور بررسى نظر شما در مورد وضعيت تان طراحى شده است. لطفا هر سوال را باضربدر زدن(x) ياسخ دهيد.

\begin{tabular}{|c|c|c|c|c|}
\hline \multicolumn{5}{|c|}{ ا-به طور كلى وضعيت سلامت خود را پگكونه مى بينيد؟ } \\
\hline 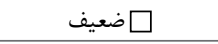 & 口 متوسط & 口 خوب & 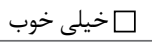 & ع ع الى \\
\hline \multicolumn{5}{|c|}{ 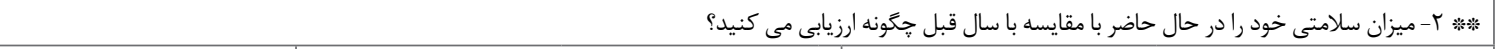 } \\
\hline ——مثل سال قبل هستم & \multicolumn{2}{|c|}{ 口 تا حدى بهتر از سال قبل هستم } & \multicolumn{2}{|c|}{ 口از سال قبل بسيار بهتر هستم } \\
\hline \multicolumn{3}{|c|}{ 口 در حال حاضر بسيار بدتر از سال قبل هستم } & \multicolumn{2}{|c|}{ 口 در حال حاضر تا حدى بدتر از سال قبل هستم } \\
\hline
\end{tabular}

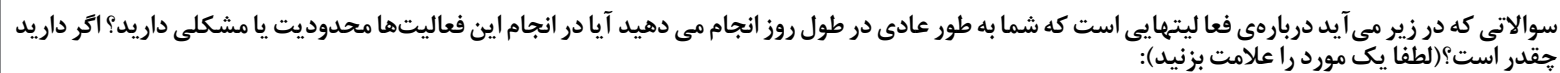

\begin{tabular}{|c|c|c|c|}
\hline 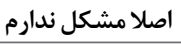 & كمى مشكل دارم & 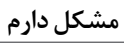 & \\
\hline & & & r-در فعاليتهاى شديد مثل دويدن، بلند كردن اجسام سنگَين، شركت كردن در ورزش هاى سنگَين \\
\hline & & & F F- درفعاليتهاى متوسط مثل جا به جا كردن ميز، كشيدن جارو برقى و... \\
\hline & & & ه- در حمل كردن خريد روزانه \\
\hline & & & צ- در بالا رفتن از جند طبقه \\
\hline & & & V- در بالا رفتن از يك طبقه \\
\hline & & & 1- خمم شدن، دولا شدن، زانو زدن \\
\hline & & & 9- ي پياده روى بيش از يك كيلومتر \\
\hline & & & • 1 - پِياده روى به فاصله جند صد متر \\
\hline & & & 11 11 يياده روى به فاصله يك صد متر \\
\hline & & & rا - در استحمام يا يوشيدن لباسهاى خود \\
\hline
\end{tabular}

\begin{tabular}{|c|c|c|}
\hline \multirow[t]{5}{*}{ خير } & بلى & در طى جههار هفته كذشته آيادر كار يا تنظيم فعا ليت روزانه خود مشكلات زير را به خاطر مشكل جسمى داشته ايد؟ \\
\hline & & با - مجبور شده ايد كه از زمان لازم براى انجام كار يا فعاليت هاى ديخر كم كنيد؟ \\
\hline & & أ|l - كمتر از آنجه كه ميخواستيد وقت كذاشته ايد؟ \\
\hline & & ها - در انجام يك نوع كار يا فعاليت خاص مشكل داشته ايد؟ \\
\hline & & عا - كار عادى خود را با سختى و مشكل بيشترى انجام داده ايد؟ \\
\hline
\end{tabular}

\begin{tabular}{|c|c|c|}
\hline \multirow[t]{4}{*}{ خير } & بلى & در طى جهار هفته حَذشته به علت مسائل رواني مثل اضطراب و يا افسردَّى در انجام امور معمولى روزانه و انجام كارها با \\
\hline & & IV - مجبور شده ايد كه از زمان لازم براى انجام كار يا فعاليت هاى ديكر كم كنيد؟ \\
\hline & & 11 - كمتر از آنجه كه ميخواستيد وقت كذاشته ايد؟ \\
\hline & & 19 - در انجام كارهاى روزمره از دقت معمول برخوردار نبوده ايد؟ \\
\hline
\end{tabular}

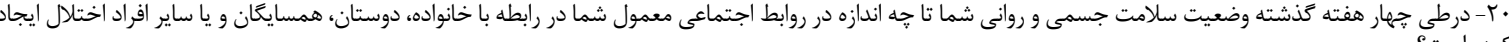

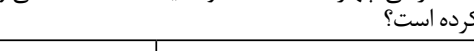

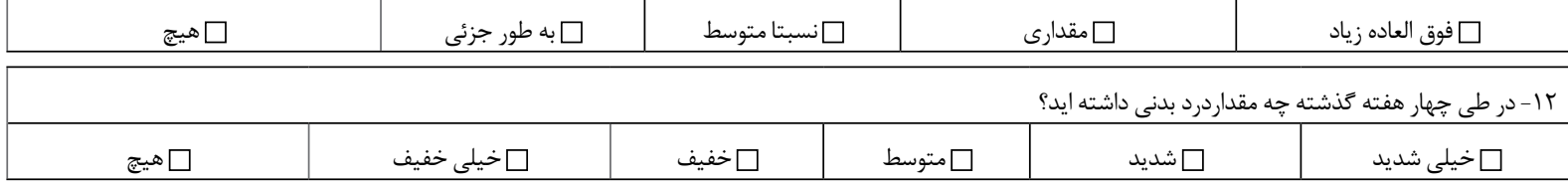




\begin{tabular}{|c|c|c|c|c|}
\hline \multicolumn{5}{|c|}{ זr- در طى קهار هفته كذشته درد بدنى تا خه اندازه مانع از انجام كارهاى عادى شما شده است؟ } \\
\hline 口 اصلا مانع نشده & ل & 口به طور متوسط & 口 تقريبا تا حدى & 口فوق العاده زياد \\
\hline
\end{tabular}

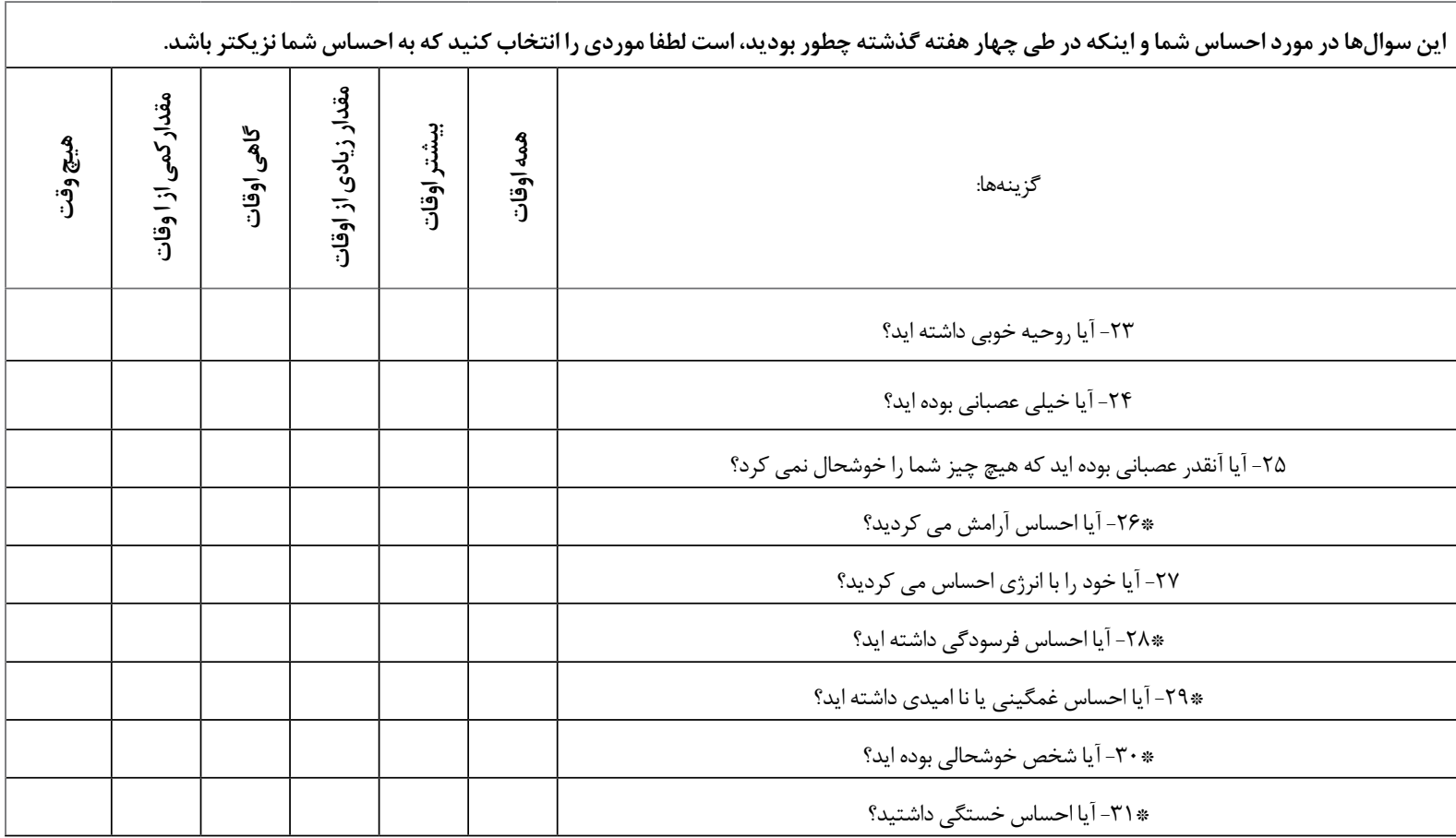

\begin{tabular}{|c|c|c|c|c|}
\hline \multicolumn{5}{|c|}{ 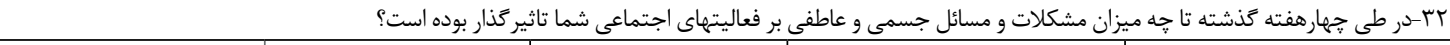 } \\
\hline 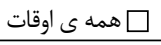 & لمبيشتر اوقات & 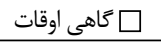 & لـ مقدار كمى از اوقات & 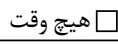 \\
\hline
\end{tabular}

\begin{tabular}{|c|c|c|c|c|c|}
\hline & & & & & موارد زير تا حهه اندازه در مورد شما صادق يا نادرست است. \\
\hline 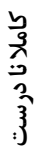 & $\begin{array}{l}3 \\
3 \\
-3 \\
3 \\
3 \\
3\end{array}$ & $\frac{3}{3}$ & $\begin{array}{l}3 \\
3 \\
\hat{3} \\
\hat{3} \\
: 3\end{array}$ & $\begin{array}{l}y \\
\frac{3}{3} \\
3 \\
3 \\
3 \\
3\end{array}$ & كزينهها: \\
\hline & & & & & با با- من از ديكران زودتر بيمار مى شوم \\
\hline & & & & & T ب - سلامت من در حد سلامت ديكران است \\
\hline & & & & & هץץ- انتظار دارم وضعيت سلامتى ام بدتر شود \\
\hline & & & & & 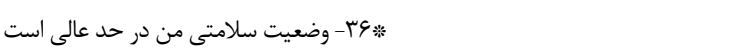 \\
\hline
\end{tabular}

* Starred items are deleted for TBI patients.

** Item 2 is not included in scoring. 